\title{
Maternal deaths: the need to rethink coping strategies
}

\author{
Óbitos maternos: necessidade de repensar estratégias de enfrentamento \\ Muertes maternas: necesidad de repensar estrategias de afrontamiento
}

Aline Cruz Esmeraldo Áfio ${ }^{1}$, Maria Alix Leite Araújo르, Ana Fátima Braga Rocha², Roumayne Fernandes Vieira Andrade $^{3}$, Simone Paes de Melo ${ }^{2}$

This study aimed to analyze maternal deaths and present the Maternal Mortality Ratio in the city of Fortaleza, in the Northeast region of Brazil, from 2008-2010. This is a descriptive study. Data collection occurred in the Mortality Information System and in the maternal death investigation files of the Local Health Department. Fifty-six maternal deaths were investigated with a Maternal Mortality Ratio of 39.75/100,000 live births. The prevalent age group was 20-29 years (50.0\%). Hypertensive disorders (50.0\%) were the most prevalent causes of direct obstetric deaths. As for indirect obstetric deaths, infectious and parasitic diseases (28.1\%) prevailed. Nearly all deaths were considered preventable or possibly preventable (91.1\%). Thus, it can be assumed that most deaths could have been avoided by ensuring the quality of prenatal care.

Descriptors: Maternal Mortality; Women's Health; Epidemiological Surveillance.

O estudo teve como objetivo analisar os óbitos maternos e apresentar a Razão de Mortalidade Materna no município de Fortaleza, Nordeste do Brasil, nos anos de 2008 a 2010. Estudo descritivo. Os dados foram colhidos do Sistema de Informação de Mortalidade e das fichas de investigação de óbito materno da Secretaria de Saúde do município. Foram analisados 56 óbitos maternos, com uma Razão de Mortalidade de 39,75/100.000 nascidos vivos. A faixa etária predominante foi de 20 a 29 anos de idade $(50,0 \%)$. Dentre os óbitos maternos obstétricos diretos, os transtornos hipertensivos foram as causas mais prevalentes $(50,0 \%)$. Nos obstétricos indiretos, foram as doenças infecciosas e parasitárias (28,1\%). Quase a totalidade dos óbitos eram evitáveis ou provavelmente evitáveis $(91,1 \%)$. Pode-se inferir que a maioria dos óbitos poderia ter sido evitada por meio da garantia da qualidade da atenção pré-natal.

Descritores: Mortalidade Materna; Saúde da Mulher; Vigilância Epidemiológica.

El objetivo del estudio fue analizar las muertes maternas y presentar la Razón de Mortalidad Materna en Fortaleza, noreste del Brasil, en los años 2008-2010. Estudio descriptivo. Los datos fueron recogidos del Sistema de Información sobre Mortalidad y de las fichas de investigación de muerte materna de la Secretaria de Salud del municipio. Se analizaron 56 muertes maternas, con Razón de Mortalidad de 39,75/100.000 nacidos vivos. El grupo de edad predominante fue de 20 a 29 años $(50,0 \%)$. Entre las muertes maternas obstétricas directas, los trastornos hipertensivos fueron las causas más frecuente $(50,0 \%)$. En los obstétricos indirectos, fueron las enfermedades infecciosas y parasitarias (28,1\%). Casi totalidad de las muertes se consideraron prevenibles o probablemente evitables $(91,1 \%)$. Se puede inferir que la mayoría de las muertes se podrían haber evitado, a través de la seguridad de la calidad de la atención prenatal.

Descriptores: Mortalidad Materna; Salud de la Mujer; Vigilancia Epidemiológica.

\footnotetext{
${ }^{1}$ Universidade Federal do Ceará, Fortaleza, CE, Brazil

${ }^{2}$ Universidade de Fortaleza. Fortaleza, CE, Brazil.

${ }^{3}$ Secretaria Estadual de Saúde da Paraíba. João Pessoa, PB, Brazil.

Corresponding author: Maria Alix Leite Araújo

Rua São Gabriel, 300. Apt 1101, Cocó. CEP: 60135-450. Fortaleza, CE, Brazil. E-mail: mleite@unifor.br
} 


\section{Introduction}

Maternal death consists of every death caused by pregnancy or its management, it can occur during pregnancy or forty-two days after it, regardless of the duration or location. For this reason, the Maternal Mortality Ratio measures the probability of women dying from causes related to the pregnant and puerperal cycle ${ }^{(1)}$.

Maternal mortality is an excellent indicator of health and inequities, since its occurrence is higher in underdeveloped and developing areas ${ }^{(2)}$. It represents a serious public health problem, considered a violation of human rights, since the cases can be prevented if women have access to quality prenatal care ${ }^{(3)}$.

Maternal deaths can be classified into direct and indirect obstetric. Direct death comprises every case resulting from complications of pregnancy, childbirth or the postpartum period; and indirect obstetric death occurs when there was a coexistence of disease before pregnancy or that developed during pregnancy and worsened by its intrinsic effects ${ }^{(1)}$.

It is estimated that 500,000 women die annually from pregnancy-related causes worldwide, about seven million of those that survive childbirth develop serious health problems, and more than 50 million experience some complication after delivery ${ }^{(4)}$.

An integrative review that brought together 50 studies on maternal mortality conducted in different regions of Brazil between 1980 and 2010 identified hypertensive diseases as the main cause of this fatality. By analyzing the preventability of deaths, it found flaws in prenatal and childbirth care ${ }^{(5)}$.

According to the report of the World Health Organization, in Brazil, from 1990 to 2008, there was a 52\% reduction in Maternal Mortality Ratio, of 120 and 58 per 100,000 live births in 1990 and 2008, respectively, with an average annual reduction of $4 \%$, even though the ideal was $5.5 \%{ }^{(6)}$.

In Brazil, only in 2012, there were 1,583 maternal deaths registered, representing a Maternal Mortality Ratio of 54.5 per 100,000 live births ${ }^{(7)}$; high numbers compared to what the World Health Organization considers acceptable, which is 20 per 100,000 live births ${ }^{(6)}$.

Study conducted in the 26 state capitals in the country including the Federal District found variations in Maternal Mortality Ratios, revealing the heterogeneity of the problem in different regions ${ }^{(8)}$.

Nevertheless, there is some difficulty in measuring rates of maternal deaths due to the lack of information and underreporting of cases. In order to achieve the millennium goals of reducing these deaths, it is necessary to know the Maternal Mortality Ratios, the trend, and identify the causes.

In this context, the present study aimed to analyze maternal deaths and present the Maternal Mortality Ratio in the city of Fortaleza, in the Northeast Region of Brazil, from 2008 to 2010.

\section{Method}

Descriptive study conducted in the city of Fortaleza, capital of the state of Ceará, located in the Northeast Region of Brazil, with 2,447,409 inhabitants, of whom 888,966 (35.5\%) are women of reproductive age $\mathrm{e}^{(9)}$.

In healthcare, a National Health System, called the Unified Health System, created by a federal law and included in the 1988 Federal Constitution provides the services. This system comprises a hierarchical network of 1,712 health facilities, including public and private services and blood banks. A network of 92 primary units and 7 secondary maternity units provides obstetric care, which are responsible for prenatal care, childbirth, and emergency obstetric care.

Initially, a survey of deaths of women of childbearing age from 2008 to 2010 took place in the Mortality Information System. The records of this system were compared to maternal deaths investigated by the Department of Epidemiological Surveillance. For this study, only the cases of maternal deaths investigated by the epidemiological surveillance cell 
and analyzed by the Committee on Maternal Mortality of Fortaleza were investigated.

Data collection occurred from March to May 2012 in the following documents: Ambulatory Health Service, Hospital Health Service, Home Interview, Synthesis, Conclusions and Recommendations, and files of Data Collection of Necropsy Records. All deaths arising from complications of pregnancy (International Classification of Diseases-10, Codes 000-099), even late maternal deaths, were included. Considering the existence of failures in filling out and sending the files, all cases that had at least the records of Ambulatory Health Service or Hospital Health Service were analyzed, since these records have more detailed information.

The variables analyzed were: Sociodemographic (age, education, race/color, if they had a partner, and health insurance); Obstetric history (number of pregnancies, abortions, and stillbirths); Prenatal care (prenatal conduct, considered highrisk pregnancy, referred to high-risk prenatal care, health problems in the last pregnancy); Obstetric care (type of delivery, health problems after childbirth, or abortion); Death (time, location and type of establishment, classification of death, preventability and basic causes).

Data were analyzed in the Statistical Package for the Social Sciences, version 19.0. In exploratory analysis, we calculated the absolute frequencies and percentages for nominal variables. In the case of quantitative variables, mean and standard deviation were presented. To calculate the Maternal Mortality Ratio, eleven deaths that occurred after 42 days of completion of pregnancy were excluded ${ }^{(1)}$.

This study is part of a larger research assessing prenatal care, childbirth, and the postpartum period and its implications in the occurrence of maternal deaths in the city of Fortaleza, Ceará. The Research Ethics Committee of the Universidade de Fortaleza approved the study under protocol No. 117.150. It is worth mentioning that it followed the standards of Resolution 466/12(10) and that the manager of the Area of Women and Gender's Health of the Local Health Department of Fortaleza signed the Custodian Statement.

\section{Results}

During the study period, 65 investigation files of maternal deaths in the epidemiological surveillance service of the Local Health Department and in the Maternal Mortality Committee of Fortaleza were found. According to the Mortality Information System, there were 52 maternal deaths in Fortaleza, with underreporting in 13 (20.0\%) cases.

On the other hand, 15 deaths analyzed by researchers were not included in the death certificates, which the World Health Organization denominates as unreported maternal death. These were confirmed after investigation of the local epidemiological surveillance, corresponding to an underreporting rate of $26.8 \%$. It is worth highlighting that nine cases were excluded from this study because they contained only death certificates, undermining the analysis of other variables, totaling 56 deaths investigated.

Table 1 describes the socio-demographic characteristics of participants. Most deaths occurred in the age group 20-29 years, 28 (50.0\%) (mean=27.7, $\mathrm{SD}=6.6$ years), and the highest proportion in relation to schooling was among women with complete or incomplete basic education, 24 (42.9\%). Most deaths occurred in brown women, 35 (62.5\%), who lived with a partner, 30 (53.6\%), and who did not have health insurance, 33 (58.9\%).

It was found that three $(7.9 \%)$ women had no income, $11(28.9 \%)$ had up to two minimum wages, and only four (10.5\%) earned from two to six minimum wages. In 2008 and 2009, 20 (52.6\%) records that did not include this information were identified and, in 2010, the income variable was excluded from the investigation form, thus hindering the analysis of this variable. 
Table 1 - Socio-demographic characteristics of women who came to maternal death

\begin{tabular}{lc}
\hline Variables & $\mathbf{n}(\mathbf{\%})$ \\
\hline Age group (years) (Mean=27.79; SD=6.68) & \\
$\leq 19$ & $08(14.3)$ \\
$20-29$ & $28(50.0)$ \\
$\geq 30$ & $20(35.7)$ \\
Education & \\
None & $2(3.6)$ \\
Complete and incomplete basic education & $24(42.9)$ \\
Complete and incomplete high-school & $12(21.4)$ \\
Complete and incomplete higher education & $2(3.6)$ \\
Ignored & $16(28.5)$ \\
Race/Color & \\
Caucasian & $7(12.5)$ \\
Black & $3(5.4)$ \\
Brown & $35(62.5)$ \\
Ignored & $11(19.6)$ \\
Lived with partner & \\
Yes & $33(58.9)$ \\
No & $20(35.7)$ \\
Ignored & $56(100.0)$ \\
Health insurance & $11(19.6)$ \\
Yes & \\
No & \\
Ignored & \\
\hline & \\
& \\
&
\end{tabular}

Table 2 discusses the obstetric history and prenatal care of women who came to maternal death. It was found that 33 (58.9\%) were multiparous (mean of 2.94 pregnancies), 11 (26.2\%) had a history of abortion, and five (11.9\%) of stillbirths. 33 (58.9\%) attended at least one prenatal consultation, 11 $(33.3 \%)$ were classified with some risk factor and eight of these $(72.7 \%)$ were treated at high-risk prenatal care.

It was possible to identify that $34(60.7 \%)$ women presented some health problems during pregnancy, such as hypertension (14.7\%), heart disease (11.8\%), and HIV/AIDS (11.8\%). In 50\% of the files, there was no record of health problems (Table 2).
Table 2 - Maternal deaths according to obstetric history and prenatal care

\begin{tabular}{|c|c|}
\hline Variables & n (\%) \\
\hline \multicolumn{2}{|c|}{ Past pregnancies (Mean=2.94; SD=2.39) } \\
\hline None & $6(10.7)$ \\
\hline 1 & $9(16.1)$ \\
\hline$>1$ & $33(58.9)$ \\
\hline Ignored & $8(14.3)$ \\
\hline \multicolumn{2}{|c|}{ Abortions $(n=42)^{*}$} \\
\hline None & $30(71.4)$ \\
\hline$\geq 1$ & $11(26.2)$ \\
\hline Ignored & $1(2.4)$ \\
\hline \multicolumn{2}{|c|}{ Stillbirths $(n=42)^{*}$} \\
\hline None & $32(76.2)$ \\
\hline $1-3$ & $5(11.9)$ \\
\hline Ignored & 5 (11.9) \\
\hline \multicolumn{2}{|c|}{ Attended prenatal care (at least one consultation) } \\
\hline Yes & $33(58.9)$ \\
\hline No & $7(12.5)$ \\
\hline Ignored & $16(28.6)$ \\
\hline \multicolumn{2}{|c|}{ Presented health problems in the last pregnancy } \\
\hline Yes & $34(60.7)$ \\
\hline No & $6(10.7)$ \\
\hline Ignored & $16(28.6)$ \\
\hline \multicolumn{2}{|c|}{ At risk classification $(\mathrm{n}=33)^{* *}$} \\
\hline Yes & $11(33.3)$ \\
\hline No & $16(48.5)$ \\
\hline Ignored & $6(18.2)$ \\
\hline \multicolumn{2}{|c|}{ Attended high-risk prenatal care $(\mathrm{n}=11)^{* * *}$} \\
\hline Yes & 8 (72.7) \\
\hline Ignored & $3(27.3)$ \\
\hline $\begin{array}{l}\text { Total } \\
\text { Tncluding onl } \\
\text { vomen who at }\end{array}$ & $\begin{array}{l}56(100.0) \\
\text { Including only } \\
\text { n considered as }\end{array}$ \\
\hline
\end{tabular}

The pregnancies evolved to labor in 39 (69.6\%) women, 28 of these (50.0\%) children were born alive. Cesarean delivery occurred in 25 (44.6\%) women. 23 (41.1\%) maternal deaths occurred during the early postpartum period ( $\leq 42$ days) and $12(21.4 \%)$ during pregnancy. With regard to the place of occurrence, almost all, 51 (91.1\%), occurred in the hospital and $48(94.1 \%)$ of these were in hospitals of the National Health System (Table 3).

Maternal deaths were classified as direct and indirect obstetric in $42.9 \%$ and $57.1 \%$ of the cases, respectively. After evaluation of the Maternal Mortality Committee of Fortaleza, 36 (64.3\%) were considered preventable, 15 (26.8\%) probably preventable, and 
four (7.1\%) inevitable (Table 4). In 2008, the Maternal Mortality Ratio was of 41.2 deaths per 100,000 live births, in 2009 it was 34.5, and 43.5 in 2010 (Table 3).

Table 3 - Maternal deaths regarding the moment of death, classification and preventability

\begin{tabular}{|c|c|}
\hline Variables & n (\%) \\
\hline \multicolumn{2}{|l|}{ Moment of death } \\
\hline Pregnancy & $12(21.4)$ \\
\hline Abortion/after the abortion & $03(5.4)$ \\
\hline Childbirth & $05(8.9)$ \\
\hline Early postpartum period ( $\leq 42$ days) & $23(41.1)$ \\
\hline Late postpartum period ( $\geq 43$ days) & $12(21.4)$ \\
\hline Ignored & $01(1.8)$ \\
\hline \multicolumn{2}{|l|}{ Place of death } \\
\hline Home & $04(7.1)$ \\
\hline Hospital & $51(91.1)$ \\
\hline Other & $01(1.8)$ \\
\hline \multicolumn{2}{|l|}{ Type of establishment $(n=51)^{*}$} \\
\hline Unified Health System & $48(94.1)$ \\
\hline Insurance/Private & $01(2.0)$ \\
\hline Ignored & $02(3.9)$ \\
\hline \multicolumn{2}{|l|}{ Classification of death } \\
\hline Direct obstetric & $24(42.9)$ \\
\hline Indirect obstetric & $32(57.1)$ \\
\hline \multicolumn{2}{|l|}{ Preventability } \\
\hline Preventable & $36(64.3)$ \\
\hline Probably preventable & $15(26.8)$ \\
\hline Inevitable & $04(7.1)$ \\
\hline Ignored & $01(1.8)$ \\
\hline
\end{tabular}

It was possible to correct the underlying cause of death in 19 (33.9\%) of the death certificates. Among those deaths classified as direct obstetric, the main causes were Eclampsia and Pre-Eclampsia/ Hypertensive Disorders of Pregnancy (50.0\%) and abortion (16.7\%).

In the indirect obstetric deaths, there was prevalence of infectious and parasitic diseases (28.1\%), respiratory $(21.9 \%)$ and cardiovascular (12.5\%) diseases.

The calculation of the Maternal Mortality Ratio does not include the cases of late maternal death ${ }^{(1)}$, therefore, 11 deaths occurring 43 days through 1 year after termination of pregnancy were excluded, totaling
45 maternal deaths. In the same period, 113,198 births occurred, determining a Maternal Mortality Ratio of 39.75 per 100,000 live births (Table 4).

Table 4 - Maternal deaths, live births and maternal mortality rati

\begin{tabular}{lccc}
\hline Year & Maternal deaths & Live births & $\begin{array}{c}\text { Maternal } \\
\text { mortality ratio }\end{array}$ \\
\hline 2008 & 16 & 38,798 & 41.2 \\
2009 & 13 & 37,645 & 34.5 \\
2010 & 16 & 36,755 & 43.5 \\
Total & 45 & 113,198 & 39.7 \\
\hline
\end{tabular}

\section{Discussion}

Socio-demographic aspects have been considered risk factors for maternal mortality ${ }^{(11-12)}$. There was a higher incidence of deaths in young women with a history of past pregnancies. Given this fact, it is essential to develop strategies for dealing with this problem, since the vast majority of these deaths were preventable. It is worth mentioning that multiparity is considered a gestational risk factor ${ }^{(13)}$. Multiparous women do not perform or do not attend all prenatal appointments, because they feel safe from the previous experiences ${ }^{(14)}$.

The analysis of the number of prenatal consultations was compromised because the files considered the pregnant women who attended at least one appointment as having received prenatal care. Another study conducted in the city of Fortaleza found similar difficulty to obtain this record ${ }^{(15)}$. It is worth highlighting the importance of quality prenatal care and improving the access ${ }^{(16)}$ of women so they begin it early and attend all appointments.

It is known that is possible to prevent, identify and/or correct the maternal and fetal outcomes in the prenatal period, favoring a good prognosis in childbirth and postpartum. It is noteworthy that $48.5 \%$ of pregnant women were not classified as at risk when they began prenatal care. It is possible the risk factors arose in the gestation process or that occurred some 
fault in their classification by professionals.

As for the completion of pregnancy, most have evolved to childbirth (69.6\%), a similar finding to other studies conducted in Fortaleza ${ }^{(15)}$. The most common type of delivery was cesarean (44.6\%), which is consistent with the literature, because cesarean delivery is indicated in urgent situations in order to preserve the lives of everyone involved ${ }^{(13)}$.

As regards the time of death, it was verified that most (41.1\%) occurred in the early postpartum period, a similar situation to that reported in the city of Recife ${ }^{(14)}$. In this context, it reveals the importance of care during the postpartum period still in the maternity ward, in the community through home visits, and the gynecological examination 45 days after delivery.

Regarding the preventability factor, it was found that the vast majority was classified as preventable/ probably preventable and with higher proportion of deaths from indirect obstetric causes. These deaths can be prevented with early onset of a quality prenatal care, as it enables the health professional to identify the occurrence of complications, detect possible pathologies, and initiate treatment in a timely manner. It is worth mentioning that the direct obstetric deaths are intrinsically related to pregnancy and the indirect to pre-existing diseases of the mother ${ }^{(1)}$.

Hypertensive disorders such as eclampsia, preeclampsia and hypertensive disorders of pregnancy were the most frequent causes of death in the study. Research conducted in a municipality of the state of São Paulo with 179 women with eclampsia found that all had inadequate prenatal follow-up resulting in specific mortality of eclampsia of 22.24 deaths per 100,000 live births ${ }^{(3)}$. For this reason, it is necessary to emphasize the importance of assisting women in this period in order to prevent maternal death.

This study enabled the identification of flaws in the record of maternal deaths in the Mortality Information System, finding underreporting of $20 \%$ of total cases. Another study conducted in the Brazilian state capitals found similar errors, with underreporting of $16 \%$ of the cases ${ }^{(8)}$. Given this reality, we realize the difficulty, also present in Fortaleza, to know the magnitude of the problem of deaths in pregnant women, a situation that compromises the development of coping strategies.

The commitment of records in relation to the quantity and quality of cases of maternal mortality is globally known. Numerous reasons can be attributed to this deficiency, from a possible inability of physicians to correctly complete the death certificate, to even the lack of significance of these data for public health ${ }^{(8)}$.

The death certificate is the standard document used for completion of the Mortality Information System ${ }^{(17)}$. Nevertheless, when analyzing the statements, underreporting was identified in $26.8 \%$ of cases. Similar situation occurred in a survey conducted in Jundiaí, in the state of São Paulo, with a rate of $50 \%$ from 1999 to $2006^{(18)}$.

It is worth noting that the Ministry of Health published the Ordinance No. 653, establishing the maternal death as a mandatory notifiable event, and since the death certificate is the document used to this purpose, it becomes mandatory the proper completion for real enumeration of cases $^{(19)}$. The maternal mortality committees and the epidemiological surveillance service were the measures adopted in Brazil for investigating all deaths of women of childbearing age in the attempt to minimize these serious problems of underreporting ${ }^{(19)}$.

Considering that the Maternal Mortality Ratio is an indicator of quality of prenatal care, a rate of 39.8 per 100,000 live births is considered "average" according to the parameters set by the World Health Organization $^{(6)}$. Nonetheless, it is below the average found in other Brazilian state capitals ${ }^{(14,20)}$.

\section{Conclusion}

Most deaths occur in young women, with low education, and that were in stable relationships. Health professionals, particularly nurses in primary care, can contribute greatly to the prevention of 
maternal deaths through welcoming with risk rating, ensuring the quality of prenatal care and early referral of cases that present any complication.

This study aims at contributing to deepen the knowledge about the risks in pregnancy, childbirth and the postpartum period, as well as knowing the situation of health care to women.

Limitations of the study included the difficulty in exploring the data, since important variables to study maternal death were not included in the records or the files were not filled out correctly. Furthermore, there was also the lack of statistical tests to verify the possible factors associated with maternal death.

Thus, we identify the need for developing strategies to elucidate the professionals responsible for the completion of the investigation files of maternal death on the importance of this information to achieve the millennium goals of reducing the number of maternal deaths by 2020 .

It is suggested to perform studies aimed at improving the knowledge of health professionals about the health care of women in the pregnant and puerperal cycle.

\section{Collaborations}

Áfio ACE, Rocha AFB, Andrade RFV and Melo SP contributed substantially to the design, planning, analysis and interpretation of data, and drafting of the article. Araújo MAL participated in the analysis, drafting and critical review of the article.

\section{References}

1. Organização Munidal de Saúde (OMS). Classificação Internacional de Doenças e de Problemas relacionados à Saúde. Geneva: OMS; 2008.

2. Wilmoth J, Mathers C, Say L, Mills S. Maternal deaths drop by one-third from 1990 to 2008: a United Nations analysis. Bulletin of the World Health Organization [Internet] 2010 [cited 2014 jun 13]; 88:718. Available from: http://www.who. int/bulletin/volumes/88/10/10-082446/en/

3. Novo JLVG, Gianini RJ. Mortalidade materna por eclâmpsia. Rev Bras Saúde Mater Infant. 2010; 10(2):209-17.

4. World Health Organization (WHO). Managing eclampsia. Educational Material for teachers of midwifery. Department of Making Pregnancy Safer. Family and Community Health. Geneva: WHO; 2006.

5. Morse ML, Fonseca SC, Barbosa MD, Calil MB, Eyer FPC. Mortalidade Materna no Brasil: o que mostra a produção cientifica dos últimos 30 anos? Cad Saúde Pública. 2011; 27(4):623-38.

6. World Health Organization/United Nations Children's Fund/United Nations Population Fund/ World Bank. Trends in maternal mortality: 1990 to 2008. Estimates developed by WHO, UNICEF, UNFPA and The WorldBank [Internet].2010 [citado 2013 out 8]. Available from: http://whqlibdoc. who.int/publications/2010/9789241500265_ eng.pdf

7. Ministério da Saúde (BR). Informações de saúde. [citado 2014 ago 18]. Disponível em: http://www2.datasus.gov.br/DATASUS/index. php?area $=0205 \&$ VObj $=$ http: $/ /$ tabnet. datasus. gov.br/cgi/deftohtm.exe?sim/cnv/mat10

8. Luizaga CTM, Gotilieb SLD, Jorge PHPM, Laurenti R. Mortes maternas: revisão do fator de correção para os dados oficiais. Epidemiol Serv Saúde. 2010; 19(1):7-14.

9. Instituto Brasileiro de Geografia e Estatística (IBGE). Contagem da população, 2010 [citado 2013 out 8]. Disponível em: http://www.ibge. gov.br/censo2010/primeiros_dados_divulgados/ index.php?uf=23

10. Ministério da Saúde (BR). Conselho Nacional de Saúde. Resolução no 466 de 12 de dezembro de 2012. Dispõe sobre as diretrizes e normas regulamentadoras de pesquisas envolvendo seres humanos. Brasília: Ministério da Saúde; 2012.

11. Keffler K, Souza SRRKS, Wall ML, Martins M, Moreira SDR. Características sociodemográficas e mortalidade materna em hospital de referência na cidade de Curitiba-Paraná. Cogitare Enferm. 2010; 15(3):500-5.

12. Leite RMB, Araújo TVB, Albuquerque RM, Andrade 
ARS, Neto Duarte PJ. Fatores de risco para mortalidade materna em área urbana do Nordeste do Brasil. Cad Saúde Pública. 2011; 27 (10):197785.

13. Ministério da Saúde (BR). Gestação de alto risco. Manual Técnico. Brasília: Ministério da Saúde; 2010.

14. Correia RA, Araújo HC, Furtado BMA, Bonfim C. Características epidemiológicas dos óbitos maternos ocorridos em Recife, PE, Brasil (20002006). Rev Bras Enferm. 2011; 64(1):91-7.

15. Herculano MMS, Veloso LM, Teles LMR, Oriá MOB, Almeida OS, Damasceno AKC. Maternal deaths at a Public Maternity Hospital in Fortaleza: an epidemiological study. Rev Esc Enferm USP. 2012; 46(2):295-301.

16. Castro ME, Vasconcelos MA, Silva LMS. Qualidade da assistência pré-natal: uma perspectiva das puérperas egressas. Rev Rene. 2010; 11(n. esp.):72-81.
17. Ministério da Saúde (BR). Manual dos Comitês de Mortalidade Materna. Série A. Normas e Manuais Técnicos. Brasília: Ministério da Saúde; 2007.

18. Matias JP, Parpinelli MA, Nunes MKV, Surita FGC, Cecatti JG. Comparação entre dois métodos para investigação da mortalidade materna em município do Sudeste brasileiro. Rev Bras Ginecol Obstet. 2009; 31(11):559-65.

19. Ministério da Saúde (BR). Portaria n. 0 653/GM, de 28 maio de 2003. Estabelece que o óbito materno passe a ser considerado evento de notificação compulsória para a investigação dos fatores determinantes e as possíveis causas destes óbitos, assim como para a adoção de medidas que possam evitar novas mortes maternas. Brasília: Ministério da Saúde; 2003.

20. Kale PL, Costa AJL. Maternal deaths in the city of Rio de Janeiro, Brazil, 2000-2003. J Health Popul Nutr. 2009; 27(6):794-801. 